\title{
The development of Brazilian studies in France
}

\section{O desenvolvimento de estudos sobre o Brasil na França}

\author{
Edward A. Riedinger \\ Ohio State University Main Library \\ 1858 Neil Ave. Mall rm. 312 \\ 43210-1286 Columbus Ohio \\ riedinger.4@osu.edu
}

\section{France and Brazil}

$\mathrm{T}$ hroughout the five centuries of the history of Brazil, four major countries have been keenly interested and influential in its development. During the first three centuries Portugal dominated, interrupted by Spanish and Dutch interventions during the first part of the seventeenth century. In the last half of the twentieth century the United States has been most significant. During the first half of the twentieth century and throughout the nineteenth century it was Britain and especially France that were foremost in interest and influence. It should be noted that, due to immigration, Italian culture and sociopolitical influence were important from the end of the nineteenth century to the middle of the twentieth.

British concerns and importance were primarily of a commercial and technical nature. During the nineteenth century, railroads, ports, shipping, wholesaling, some aspects of financing and insuring, electrical communications, and athletic activities followed British patterns. A medical doctor, Andrew Grant, wrote the earliest history in English, entitled a History of Brazil, comprising a geographical account of that country, together with a narrative of the most remarkable events which have occurred there since its discovery. It appeared in London in 1809, just after British merchants were given preferential trading privileges in Brazil. It was prepared to caution readers about the region's insalubrious climate. However, the author, intrigued by the vast exotic realm, wrote 
about it with an engaging thoroughness (somewhat anticipating the first tourist guides of Thomas Cook). Shortly after the English edition, French (Histoire du Brésil, 1811) and German (Andrew Grant's ... beschreibung von Brasilien, 1814) ones appeared, the French edition completed in Russia. Czar Alexander I would finance the monumental 1821-29 Langsdorff expedition through Brazil. (Andrew Grant appeared as the shortest entry in the first edition of the Dictionary of National Biography.)

It was France, however, as the leader of the Latin cultural world, that had the most influence; and Brazil was one of the largest Latin countries. The term 'Latin America' originated from the pan-Latin ideas of the French economist Michel Chevalier during the early part of the reign of Napoleon III (who occupied Mexico during the US Civil War). The French sought to lead a Latin cultural bloc as a geo-political pawn against Anglo, Germanic, and Slavic blocs. During the same period France promoted a 'Latin' Monetary Union of itself, Belgium, Switzerland, and Italy (an effort defeated by the profligacy of Vatican State accounts). From Ravel and Bizet on, French composers created a Latin repertoire against the Germanic Wagnerian advance, elaborating some of the most memorable Spanish themes in classical music and a revival in French of Italian opera.

With the opening of the port of Rio de Janeiro in 1808 and until after the Second World War, French customs and manners dominated the Brazilian professions, especially medicine, sanitation, engineering, diplomacy, and law. Architecture and interior design, whether public or private, successively reflected the French neo-classical, beaux arts, art nouveau, and art deco styles. Banking, luxury retailing, elite social and culinary manners, and leisure indulgences were French. In education, the administrative model and the second language of the school curricula were French together with the organization of music and art education, libraries, museums, and fine arts exhibitions. Literature (belles-lettres) and publishing were French. Exceptions to this influence, other than the British, occurred in religious architecture and in clerical culture, which in their upper hierarchical and urban manifestations were Italian, though with some Gallican Church variations. Military organization and engineering changed at the turn of the century from French to German.

Unlike Brazilian studies in the US, French interest in and focus on Brazil has roots almost as deep as Brazilian history itself. Indeed, before there was even an English presence in the Americas, the French were studying and publishing on Brazil.

The French attempt in the mid-sixteenth century to create France Antarctique in the Bay of Guanabara prompted the Portuguese to eradicate the French settlement and found Rio de Janeiro. One of the expelled leaders, Jean de Léry, wrote the first French classic on the country, Histoire d'un voyage fait en la terre du Brésil (1580). A woodcut 
of 1551, portraying a triumphal procession into Rouen by Henry II and his consort, Catherine of Medici, includes a 'Figure des Brasilians' that depicts life and warfare among Tupinamba and Tapajó natives.

At the beginning of the seventeenth century, the French attempted to establish a France Équatoriale east of the mouth of the Amazon River, prompting the Portuguese to once again expel them, taking over the French settlement of São Luís in Maranhão. As late as 1905 French gunboats in the mouth of the Amazon challenged Brazilian sovereignty over Amapá, bordering French Guyana.

With the seat of the Portuguese monarchy settled in Brazil after 1808, King João VI invited a group of French artists and technicians to embellish and survey his vast realm, an undertaking described in A missão artistica de 1816 (1983). Along with Grant's history of Brazil in French, there shortly afterward appeared histories of Brazil in French by Alphonse de Beauchamp (1815 and 1824 [on the country's recent independence]), Hippolyte Taunay (1822), and Ferdinand Denis (1825). The first doctoral dissertations at the Sorbonne on Brazil appeared in 1823: Geographie de la province cis-platine $d u$ Brésil and Hygiène publique à Rio de Janeiro. They follow the social-utilitarian scientific focus that was the purpose of the new doctoral degrees then resulting from Napoleonic reforms of higher education.

An early economic study of Brazil, over three hundred pages long, by a classic liberal French economist, Horace Say (younger brother of Jean-Baptiste - Say's Law) is of special curiosity. In Histoire des relations commerciales entre la France et le Brésil et considérations générales sur les monnaies, les changes, les banques et le commerce extérieur (1839), he advances neo-liberal arguments still occurring among international bankers, funding agencies, and the Brazilian government. For the end of the nineteenth century, Jeffrey Needell has detailed the intensity of French influence in A Tropical Belle Époque: elite culture and society in turn-of-the-century Rio de Janeiro (1987).

France singularly influenced the concentrated development of modernism in Brazil. The ideological axis for the abolition of slavery and the establishment of the Republic originated from French positivism. Marc Ferrez inaugurated Brazilian photography. Machado de Assis founded the Brazilian Academy of Letters, modeling it on the French institution, replicating even the uniforms of "les imortelles." Heitor Villa-Lobos spent the nineteen-twenties in Paris, obtaining access to Parisian music publishers and impresarios through Arthur Rubinstein. Darius Milhaud composed many pieces with themes originating from his years in Brazil. Brazilian organ compositions by Amaral Vieira, Alberto Nepomuceno, and Henrique Oswald followed patterns of César Franck, Charles-Marie Widor, and Marcel Dupré.

The Brazilian painters Anita Malfatti, Tarsila do Amaral (a student of Fernand Léger), José Lins do Rego, Emiliano Di Cavalcanti, and Cândido Portinari regularly exhibited in Paris salons and were distinguished 
members of the École de Paris. The sculptors Victor Brecheret and Bruno Giorgi studied with or followed Auguste Rodin and Aristide Maillol (along with the Italian, Arturo Dazzi). The Archives Nationales de France sponsored a major exposition of Brazilian art in 1955 (catalog: France et Brésil, Paris: Hotel de Rohan).

Writers such as Paul Claudel, Blaise Cendrars, and Georges Bernanos lived and traveled in Brazil, later writing about these experiences. Le Corbusier (the Franco-Swiss architect Charles-Edouard Jeanneret) was the key mentor of Oscar Niemeyer. The revival of Brazilian drama followed innovations appearing in Parisian theater. Since 1963 Moliére Prizes, based on the Paris theater critics prize of the same name, have been annually awarded for outstanding performance in Brazilian theater. These are presented at Rio de Janeiro's Municipal Theater, which was modeled on the Opéra de Paris.

The long history of French and Brazilian cultural interchange has recently been narrated by Mario Carelli in Cultures croisées: histoire des échanges culturels entre la France et le Brésil, de la découverte aux temps modernes (1993), published in Portuguese as Culturas cruzadas: intercâmbios culturais entre França e Brasil (1994). Aspects de la coopération franco-brésilienne: transplantation culturelle et stratégie de la modernité by Guy Martinière further studies this cultural relationship in terms of modernism (1982). The force of the influence of French thinking on modern Brazilian culture and society is studied in Sérgio Miceli's Intelectuais e classe dirigente no Brasil (1920-1945) (1979) = Les intellectuels et le pouvoir au Brésil (1920-1945) (1981).

In the last half of the twentieth century, the French role in Brazil has considerably declined. Furthermore, France itself has succumbed to extensive American influence. Nevertheless, due to the country's long interest and historic cultural role in Brazil, modern French academic study of Brazil, which extends from the 1930s to the present, has been considerable, significant, and grown.

\section{Modern French study of Brazil}

The University of São Paulo, the 1930s

The founders of the Universidade de São Paulo (USP) in 1934 resolved that the quality of the institution would depend upon attracting the finest young scholars from European universities. Simon Schwartzman in A space for science: the development of the scientific community in Brazil (1991, from the Pennsylvania State University Press) has written that:

There is no single register (at USP) of the persons invited, those who actually came, or the duration of their stay. The first group included, from France, Paul Arbusse Bastide (sociology), Emile 
Coornaert (history of civilization), Robert Garric (French literature), Pierre Deffontaines (geography), Etienne Borne (philosophy and psychology), and Michel Berveiller (Greco-Roman literature); from Italy, Francesco Picollo (Latin), Luigi Fantappié (mathematical analysis, integral and differential calculus), Ettore Onorato (mineralogy), and Gleb Wataghin (theoretical physics); from Germany, Ernest Breslau (zoology), Heinrich Rheinboldt (chemistry), Felix Rawitscher (botany); and from Portugal, Francisco Rebelo Gonçalves (Portuguese literature).

Besides those, the university's first yearbook, for 1934-35, lists Jean Mougé, Pierre Monbeig, Fernand Braudel, Claude Lévi-Strauss, Edgar Otto Gothsch, and Pierre Hourcade, all from France, ... a second wave brought Ernst Marcus, Paul Vanorden Shaw, François Perroux, Luigi Galvani, Giacomo Albanese, Giuseppe Ungaretti, Georges Readers, and Ottorino de Fiori Cropani. Marcus was to replace Breslau, who died suddenly. Most professors came for a short period and returned after the first year. They were often replaced by others from the same country, such as Jean Gagé, Pierre Fromont, Roger Bastide, Alfred Bonzon, Karl Arens, and Atílio Venturi.

Classes started on 11 March 1935 with forty-six students in philosophy, twenty-nine in mathematics, ten in physics, twentynine in chemistry, fifteen in the natural sciences, sixteen in geography and history, eighteen in the social and political sciences, five in classical literature and Portuguese, and nine in other foreign languages. source:http://www.http://www.airbrasil.org.br/simon/

As can be seen, the major contingent of scholars was French. Those involved with the social sciences were influenced by the concept of the science de l'homme, the study of humankind based on an integrated perspective of psychology, sociology, and anthropology together with philosophy and economics. The extent of such French study in field research in Africa and Asia, gave it a particular focus on tropical lands and environments and on stages of culture and civilization among a vast array of native peoples.

To select young French academics, the USP founders consulted with specialists in philosophy, psychology, and anthropology such as Georges Dumas, Pierre Janet, and Paul Rivet. The young scholars these French consultants recommended determined what and how the French have studied Brazil even until today. The production and influence of some of the principal USP generation of French specialists on Brazil comprised:

- Paul Arbousse-Bastide: writing primarily on positivist educational philosophy, his principal work related to Brazilian education was Formando o homem: contribuição para o plano de um ginásio 
ideal (1944) with an introduction by the singular Brazilian educator, Fernando de Azevedo. Arbousse-Bastide also wrote an introduction for a book by Gilberto Freyre.

- Roger Bastide: with pioneering social and psychological studies of Afro-Brazilian religion, he produced such seminal works as Images $d u$ Nordeste mystique en noir et blanc (1945), Brésil, terre des contrastes (1957), Le candomblé de Bahia, rite Nagô, et autres essais (1958), Les religions africaines au Brésil; vers une sociologie des interpenetrations de civilisations (1960). Bastide's work on African culture and religion in Brazil was given continuity in that of Pierre Verger and numerous scholars since.

- Fernand Braudel: the great Annales historian began his university career at USP, in residence from 1935 to 1938. He published little, however, on Brazil. Imprisoned after the start of WWII, he spent his time writing his famous work on the Mediterranean during the reign of Philip II. An economic research institute is named after Braudel at USP, inaugurated in 1987.

- Pierre Deffontaines: a geographer and topographer of wide ranging interests in the Americas, Europe, and Asia, his principal works concerning Brazil were Geografia humana do Brasil (1940, 1952) and El Brasil, la tierra y el hombre (1944, 1960). He also wrote studies of native tribes (Mascatis and Guaycurus) and the development of Brazilian air transport.

- Pierre Fromont: a noted agricultural economist, his works on international rural economics only studied Brazil in comparative terms in relation to his principal specializations in France, Europe, Egypt, and the Middle East.

- Robert Garric: a scholar of French letters and organizer of the social worker profession in France, he did little work directly on Brazil. However, he wrote the preface for Antônio Carneiro Leão's Victor Hugo no Brasil (1960).

- Pierre Hourcade: a specialist in Brazilian and Portuguese literature, he was one of the early translators into French of Jorge Amado, publishing Bahia de tous les saints [Jubiabá] (1938).

- Claude Lévi-Strauss: in developing structural anthropology, he focused much of his work on Brazil, such as La vie familiale et sociale des indiens Nambikwara (1948) Le cru et le cuit (1964), and the classic, Tristes tropiques (1955).

- Pierre Monbeig: advancing numerous theories on regional and national aspects of geography, particularly in relation to frontier 
and borderland areas, concerning Brazil he wrote Pionniers et planteurs de São Paulo (1952), La croissance de la ville de São Paulo (1953), Le Brésil (1954), and Novos estudos de geografia humana brasileira (1957).

- François Perroux: a prolific writer on economic planning, market economies, and developing countries, he wrote little specifically on Brazil although several of his works were translated to Portuguese including Lições de economia política (1936) and O capitalismo (1974).

- George Readers: of particular relevance to French-Brazilian intellectual relations, he wrote an article, 'Dom Pedro II, ami et protecteur des savants et écrivains français' in the Revista da Universidade Católica de São Paulo (June, 1955).

\section{After USP and the Second World War, the 1950s and 60s}

The publications on Brazil of the French scholars from USP began to appear in the late forties and throughout the fifties. With the appearance of these works, an additional contingent of scholars began to emerge also focusing on Brazil.

- Germain Bazin: the author of many dozens of volumes of art history, he concentrated especially on the baroque and modern periods. Consequently he was drawn to the distinct nature of baroque art in Brazil, writing L'Architecture religieuse baroque au Brésil (2 vols., 1956-58) and Aleijadinho et la sculpture baroque au Brésil (1963). Bazin's work in this regard was indebted to the accomplishments during the preceding decades of the newly organized Instituto do Patrimônio Histórico e Artístico Nacional (Iphan) under Rodrigo Mello Franco. The architectural and artistic accomplishments of IPHAN were complemented by the work of the German musicologitst, Curt Lang, who made numerous discoveries in regard to Brazilian baroque music. (As a continuation of interest in the Brazilian baroque, an exhibition of such art occurred at the Petit Palais in Paris during 1999-2000.)

- Yves Bruand: an arts librarian at the National Library of France he was appointed professor of modern art at the University of Toulouse. One of the foremost authorities on modern Brazilian architecture, he is the author of L'architecture contemporaine au Brésil (1971) = Arquitetura contemporânea no Brasil (1981, 1997).

- Raymond Cantel: noted for his multi-edition Portuguese grammar in French, Précis de grammaire portugaise, he also specialized in the writings of padre Antonio Vieira, Les sermons de 
Vieira: étude du style (1959) and Prophétisme et messianisme dans l'oeuvre d'Antonio Vieira (1960). In addition he published two works on literatura de cordel.

- Jacques Chonchol: his work on Brazil has focused on Brazil within the context of agricultural and land reforms in Latin America and Indian rights. Two of his many books have appeared in Portuguese, Metodologia para formular um programa de desenvolvimento agricola (1966) for the Superintendência do Desenvolvimento do Nordeste (Sudene) and Crise e transformação dos regimes autoritários (1986).

- Benjamin Coriat: focusing on theories of enterprise, such as Fordism and Taylorism, and the exercise of entrepreneurial culture in France and Japan, he also written on socio-economic implications of robotics and electronics. On Brazil he wrote Alcool: enquête au Brésil sur un programme agro-énergétique de substitution au pétrole (1982), the innovative way in which Brazil, a petroleum poor country, came to substitute sugarcane alcohol for gasoline in motors.

- Guy Martinière: specializing in cultural and educational relationships between Brazil, the lusophone world, and France, he has published Aspects de la coopération franco-brésilienne: transplantation culturelle et stratégie de la modernité (1982) and France-Brésil, vingt ans de coopération (1989).

- Frédéric Mauro: prolific economic historian, he wrote on the expansion of modern Europe, especially in the Americas and the Atlantic. In relation to Brazilian history, he produced volumes on each century of its development along with a multi-edition, standard, one-volume history of Brazil: Do pau-brasil ao açucar, estruturas econômicas e instituições politicas: $1530-1580$ (1971), Études économiques sur l'expansion portugaise, $1500-1900$ (1970), Histoire du Brésil (1973, 1979, 1994), La formation économique du Brésil: de l'époque coloniale aux temps modernes (1974), Do Brasil à América (1975), Le Brésil du XV e à la fin du XVIII e siècle (1977), La vie quotidienne au Brésil au temps de Pedro Segundo: 1831. 1889 (1981), Le Portugal, le Brésil et l'Atlantique au XVII ${ }^{e}$ siècle : 1570-1670: étude économique (1983), La préindustrialisation du Brésil: essais sur une économie en transition: 1830-50-1930-50 (1984), O império luso-brasileiro: 1620-1750 (1991).

- Kátia Mytilineou de Queirós Mattoso: a Brazilian scholar in France, she is the author of numerous insightful books in French and Portuguese on slavery, Bahia, and colonial Brazil. One of her most noted and effective works has been Etre esclave au Brésil: XVI ${ }^{e}$. XIXe $^{\text {(1979) }}=$ To be a slave in Brazil, 1550-1888 (1986). 
- Daniel-Henri Pageaux: although a specialist in Portuguese literature, his Latin American interests include authors such as Ernesto Sábato and Aimé Césaire. A further interest in comparative literature thereby encompasses Brazilian literature in relation to Latin America and the lusophone world.

- Jean Roche: a specialist on Rio Grande do Sul, he wrote L'administration de la province du Rio Grande do Sul de 1829 à 1847 d'après les rapports inédits du président du Rio Grande do Sul devant le Conseil Général, puis l'Assemblée Législative Provinciale (1961) and A colonização alemã e o Rio Grande do Sul (1969) = La colonisation allemande et le Rio Grande do Sul.

- Michel Rochefort: a geographer specializing in rivers and South America, Brazil, Senegal, and Alsace, he wrote Rapports entre la pluviosité et l'écoulement dans le Brésil subtropical et le Brésil tropical Atlantique, étude comparée des bassins du Guaïba et de Paraïba do Sul (1958).

- Ignacy Sachs: a leading economist regarding strategies for Third World economic development and environmental preservation, he is the author of Resources, employment, and development financing: producing without destroying: the case of Brazil (1989) and the Unesco publication, Extractivism in the Brazilian Amazon: perspectives on regional development (1994). He was a leader at the 1992 Rio Conference. He wrote the preface for Le Brésil après le miracle (1987) by Celso Furtado.

French study and writing on Brazil are centuries-old. French intellectual and cultural influence on the country was even paramount during much of the nineteenth and into the early twentieth century. What distinguishes the study of Brazil in France? In relation to the modern American focus of Brazilian studies, several characteristics are apparent:

1) French work is primarily in the social sciences or socially relevant physical sciences. However, it rarely focuses exclusively on Brazil. In part this could be due to fewer academic or research positions in France exclusively for Brazil. Generally Brazil is studied only as a 'case' within the context of a particular disciplinary focus or hypothesis such as the psychology of religion, literature in Portuguese, Third World economies, tropical native peoples, agriculture, ecology etc. The approach is more horizontally integrated than vertically. Nonetheless, the term brésilianiste has begun to appear. However, the spelling preserves the 'a' of the English term, a recondite example of franglais.

2) Although the volume of French work on Brazil is smaller than the American, the historical extent of it is centuries old, going back to the 
very beginning of Brazil. Production of the last half century is of a wide, integrative nature, several works, especially in anthropology and social psychology, having become seminal classics.

3) In relation to economic theory, the dependency paradigm and recognition of a key role for the state hold much stronger sway among French theorists (as with Brazilian economists) than among current neo-liberal Anglo-American professionals.

4) French and Brazilian scholars share many traditions beyond just a Latin culture. There is often an ideological and social camaraderie of "subaltern elites," allowing them to operate as gadflys to the anglophone, neo-liberal social science establishment (Pierre Bourdieu possibly questioning such an enclave). Due to the modern francophone community or the older French empire, French social scientists have generations of experience in working familiarly in subtropical or tropical environments, such as the Caribbean, west Africa, the Middle East, and southeast Asia. Quite important also is the French conception of and respect for negritude, the originality of African art and culture, and the adaptive, integrative character of French civilisation.

5) Unlike the US, where most graduate students studying Brazil are American, most current graduate-level specialization on Brazil in France is done not by French but Brazilian students. However, due to factors of scholarship funding and changing interests in fields of study, the number of such students is declining.

\section{Current conditions and resources}

In addition to the scholarly works of the post-WWII period, a considerable increase has occurred in recent decades in the production of doctoral dissertations on Brazil at French universities. According to the Catalogue general des theses sauternes en France sur le Brésil (1823. 1999) (published in 2000 as an extra number of the Cahiers du Brésil Contemporarine), 1, 344 theses or dissertations (doctoral and troisième cycle, the latter is a kind of advanced masters degree requiring a thesis) have been presented at French universities. The volume has an insightful preface by Anita Pires-Saboia. More than 98 percent appeared in the period 1945 to 1999 . Most significantly, 95 percent have appeared since 1970, and 54.9 percent since 1985. At the heart of this increase, of course, was one which also affected the US, the expansion of higher education.

Almost half (49.9 percent ) the dissertations have appeared in the disciplines of economics (22.6), sociology (14.1), and geography (13.2). Another three fields, literature (12.4), education (8), and history (7.5) bring total coverage to 77.8 percent. The remaining areas are the anthropology (6.3), law (5.5), the arts (4.3), political science (3.6), and 
psychology (2.3). The social sciences overwhelmingly dominate and the tradition of the science d l'homme.

The expansion of study of Brazil occurred due to several factors. Within French higher education, the number of universities increased by approximately 150 perecent after the student uprisings of May, 1968. Just in Paris during the decade of the seventies, the Universite de Paris became thirteen different institutions, the Sorbonne remaining as a core remnant. Located throughout the city, the new universities adopted more modern curricula, including such things as business administration, and reformed degree programs, especially the doctorate. Throughout the country the number of students, programs, and institutions increased. A brief description of the nature and size of the expansion of French higher education can be read at http://www.ssn.flinders.edu.au/politics/ staff/ethos.htm.

As more university positions in more varied fields became available in France, a greater number of Brazilian students sought them. The growing repression of the military regime after 1964 forced numerous young Brazilian radicals into exile. As students enrolling in French universities, particularly in Paris, they swelled the number of theses (troisième cycle) written on Brazil. Brazilian enrollment in French sociology departments vastly increased, that discipline virtually forbidden then in Brazil.

Furthermore, the Brazilian military government gave priority to improving the country's level of higher education as a fundamental vehicle for national development. Thereby, it sponsored more financial aid through thousands of scholarships for doctoral study abroad. These were offered principally through the Conselho Nacional de Pesquisa (CNPq, Ministry of Science and Technology) and the Coordenação de Aperfeiçoamento de Pessoal de Nível Superior (Capes, Ministry of Education and Culture). Although most students with these grants chose to study in the US, the second alternative, especially in the 1980s, was France. Thereby a further increase in French doctoral dissertations on Brazil appeared.

Tracing the study of Brazil in France has greatly been enhanced by the database FRANCIS. Produced by L'Institut de l'Information Scientifique et Technique du Centre National de la Recherche Scientifique, it "indexes multilingual, multidisciplinary information published in over 4,200 journals covering the humanities (67\% [sic]), social sciences (30\%), and economics (3\%). The database is strong in religion, the history of art, psychology, and literature (with particular emphasis on current trends in European and world literature). It contains bilingual (English-French) subject descriptors. Particularly noteworthy is the inclusion of abstracts in $80 \%$ of the records. FRANCIS represents a wide range of materials, including serials, journal articles, books, book chapters, conference papers, French dissertations, exhibition catalogs, legislation, teaching materials, and reports" (from Research Libraries Group statement). 
FRANCIS allows subject and keyword searching in French. Moreover, it allows limiting of searches by location to publications in France. In this way, a search for a Brazilian subject or keyword allows a fairly precise count of what has been the French research on that topic for nearly the past two decades.

In terms of where in France research is and can be done on Brazil, there are several key libraries and centers. While mostly in Paris, several exist in cities of the provinces. Below is a list of current resources. For previous sources of such information, see the Répertoire des Recherches latino-amèricanistes en France, no 1 (1979) and the Répertoire des Recherches latino-américanistes en France, no 2 (1982), edited by the Groupe de Recherches sur l'Amérique Latine (GRAL) at the Université de Toulouse-le-Mirail; and Latinoamericanistas en Europa: registro biobibliográfico de 1990 by Jean Stroom and Latinoamericanistas en Europa: registro bio-bibliográfico de 1995, from the Centro de Estudios y Documentación Latinoamericanos (CEDLA) in Amsterdam.

\section{Paris}

\section{Bibliothèque Nationale de France}

Quai François-Mauriac 75706 Paris Cédex (Cedex V.L.17)13

Tel.: 0153795959

Web: http://www.bnf.fr

Material on Brazil at the National Library of France (both the old site, rue Richelieu, and the new, Mauriac) can be found through the English-language work, Resources for Brazilian Studies at the Bibliothèque Nationale [de France] (1980) by William Vernon Jackson. The new national library has been built since this book was published; nevertheless, the work is still quite useful since it describes holdings in call number groupings. Many that were at the Richelieu location are now at the Mauriac.

Centre de Recherches sur le Brésil Contemporain (CRBC)

École des Hautes Études en Sciences Sociales (EHESS)

Maison des Sciences de l'Homme

54 Bd. Raspail

75270 Paris Cédex 06

Tel.: 0149542085

Fax: 0145488353

E-mail: crbc@ehess.fr

Web: http://www.ehess.fr/centres/crbc/accueil.html

The CRBC is housed in the Maison des Sciences de l'Homme, founded

by Fernand Braudel. The library of the Maison houses the premier collection of science de l'homme research resources, with over 100,000 
volumes and about 2,000 current periodicals. The CRBC operates with the Institute des Hautes Études d'Amérique Latine (IHEAL, part of the Université de Paris-III). In conjunction with the Presses Universitaires de France, the CRBC publishes a monograph series on Brazil, the Collection Brasilia, begun in 1981. President Cardoso published Les idées à leur place, 1984, in this series. The CRBC has published the journal, Cahiers du Brésil Contemporain since 1987. It also maintains a databank, Banque de données France-Brésil (BDF), and a small library. The CRBC is the principal Brazilian studies center in France and was founded in 1985 by Ignacy Sachs.

The 100,000-volume library of the IHEAL, the Bibliotheque Pierre Monbeig, complements that of the CRBC. It is located at: 28, rue SaintGuillaume (75007; Tel.: 443986 76; Fax: 454879 58; Web: http:// www.iheal.univ-paris3.fr/documentation/index.html). IHEAL has also maintained a publishing enterprise since 1957, Éditions de l'IHEAL. Furthermore, it is the headquarters for the European documenting service on Latin America, the Réseau Européen d'Information et de Documentation sur l'Amérique Latine (REDIAL, http://www.eurosur.org/ REDIAL/producto.htm).

Centre de Recherche sur les Pays de Langue Portugaise (CREPAL)

Bibliothèque

Université de Paris III - Sorbonne Nouvelle

17, rue de Sorbonne, Esc. C - 2e étage

75005 Paris

Tel.: 0140462917

Fax: 0143257471

Web: http://bucensier.univ-paris3.fr/po_acc.htm

The holdings of the library of CREPAL are primarily in Brazilian, Portuguese, and lusophone African literature and the Portuguese language. The collection consists of about 30,000 volumes and nearly four hundred periodicals. Additional related resources nearby are in the adjoining building of the inter-university library of the Sorbonne and the Bibliothèque Sainte Genevieve (10, Place de Panthéon).

Centre d'Études des Pays de Langue Portugaise

Université de Paris VIII

2, rue de la Liberté

93526 Saint-Denis Cédex 02

Tel. 0149406683

The University of Paris VIII is on the northern edge of the city (Vincennes-St. Denis). Its Portuguese instruction resources depend on the university libraries in central Paris, in the Sorbonne and Panthéon areas. 
Centre d'Études sur le Brésil

Institute de Recherches sur les Civilisations de l'Occident Moderne (IRCOM)

Université de Paris IV - Sorbonne

1, rue Victor Cousin, Esc. G, Bureau 333

75230 Paris Cédex 05

Tel.: 0140462513

Fax: 0140463192

Web: http://www.paris4.sorbonne.fr/html/ufr/ircom/ircom.htm

IRCOM has a 10,000-volume library, the Bibliothèque Roland Mousnier, specializing in modern western history.

\section{Musée de ['Homme}

Bibliothèque, Fonds Bastide

Palais de Chaillot

Place du Trocadéro

75016 Paris

Tel. 0144057206

Web: http://www.paris.org/Musees/Homme/info.html

The Bastide Collection within the library of this museum holds some of the richest French resources on Brazilian ethnology and anthropology.

\section{Provinces}

\section{Rennes, Brittany}

Département de Portugais et d'Études Portugaises, Bresiliennes et de l'Afrique Lusographe

Université Rennes 2 - Campus Villejean

Pôle Langues, bâtiment L et bâtiment E 6, av. Gaston Berger 35043 Rennes Cédex

Tel.: 0299141652

E-mail: dominique.bellier@uhb.fr

Web: http://www.uhb.fr/enseignement/index.htm

The interest of this Breton university in Portuguese, and hence Brazil, is in relation to Celtic or Gaelic culture. The remaining axis of this culture extends from Ireland and western Scotland through Wales (país de Gales, in Portuguese); Brittany, in northwest France; the old Gaul parts of France; Galicia, in northwest Spain; and Portugal (name derived from the "port of the Gauls S" or Celts). 
Tours, Centre

Institut d'Études Hispaniques et Portugaises

Faculté des Lettres

Université de Tours

3, rue des Tanneurs, Bureaux 5 à 11

37041 Tours Cédex 01

Tel.: 0247366589

Fax : 0247366553

E-mail: bourreau@univ-tours.fr

Web: http://www.univ-tours.fr/espagnol/institut.htm

This is a small program for Portuguese literature that includes Latin American studies.

\section{Aix-en-Provence, Provence}

Département d'ìtudes Luso-Brésiliennes (Portugal, Brésil et Afrique de langue Portugaise)

Université de Provence - Aix-Marseille I

29, av. Robert Schuman, Bureau 327

13621 Aix-en-Provence

Tel.: 0442953030

Fax: 0442594280

Web: http://www.up.univ-mrs.fr/ werlaos

This department publishes the Cahiers d'Études Romanes for Spanish, Catalan, and Latin American studies. This publication and the department focus on Portuguese, and hence Brazil, as part of the Roman and Mediterranean world. The Université de Provence has a location in Marseille and is a member of the Conférence Française des Universités de l'Arc Méditerranéen. 